\begin{abstract}
"Mircea cel Batran" Naval Academy Scientific Bulletin, Volume XX - 2017 - Issue 2
The journal is indexed in: PROQUEST / DOAJ / Crossref / EBSCOhost/ INDEX COPERNICUS/ OAJI / DRJI I JOURNAL INDEX / I2OR / SCIENCE LIBRARY INDEX / Google Scholar / Academic Keys / ROAD Open Access I Academic Resources / Scientific Indexing Services / SCIPIOI JIFACTOR
\end{abstract}

\title{
INFORMATION AND DISINFORMATION ON MARITIME PIRACY PHENOMENON
}

\author{
Răzvan BÂZÂITU' ${ }^{1}$ \\ ${ }^{1} \mathrm{PhD}$ student Col. (r.) MAI, razvan@bazaitu.ro, Bucharest Police Academy
}

\begin{abstract}
The European Union noticed during the latest major events that traditional approach is exceeded by the new reality. Whether we are talking about international armed aggression (like Russia occupying Crimea) or tensions and threats among leaders, ISIS fighters shocking the civilised world by cutting the neck of the enemy in front of the TV camera or during live internet sessions, piracy attacks, massive groups of illegal immigrants accepted inside Europe to optimize demographic indicators but officially declared victims of conflicts which does not exist in most of the countries they come from, all lead to the common denominator - we are currently running after the crises, not managing it.

It is no surprise we have to become holistic, to show an integrative approach, specially in exceptional situations. In this fast and complicate world, one can not be clever alone, even if old differences (like north vs south or east vs west) used to divide our countries.

To fight against piracy, the classic tools are not enough. The global map is fluid and continuously moving so any analyse on fix situation is useless. The new challenge is the hybrid war, because the extreme poverty push desperate people to desperate measures. The supply of the classic political and military approach is a lose - lose game. We should have a bird's eye view on the reasons and methods of the pirates, which should be taken into account by multi-disciplinary teams of experts to understand the roots, the mentality, the channels and the final target of the phenomenon, to imagine and offer sustenaible solutions and options. At this stage, a sensitive point is a good information (at least to avoid enemy's disinformation), so the final integrative solution have to consider psychological, sociological, ethnological, cultural, religious and historical aspects.
\end{abstract}

Key Words: globalism, profiling, hybrid war, sustainability

The history, spreading and forms of piracy

The phenomenon of violent robbery on board of ships in order to steal cargo or other special value goods is known from ancient times; the first testimonies to this effect date back to the 14th century BC and they show that there were socalled Sea People who attacked the ships of the Aegean and Mediterranean civilizations. Narrowed areas, mandatory passageways (the straits and the adjacent area of the ports, for example) provided the opportunity for pirates to attack, just as ambushes were organized on land in confined spaces, in gorges or on the river's shore.

The most well-known traditional pirated areas are: Gibraltar, Malacca Strait, Madagascar, Aden Bay and British Channel. It is estimated that in 2007 (prior to the launch of the EU Operation ATALANTA), maritime piracy produced a total damage estimated at $\$ 16$ billion annually. Currently, most problems are reported in the Red Sea, Indian Ocean, Somalia Coast, Malacca and Singapore.

There is often talk of maritime robbery and piracy in order to obtain economic benefits and financial profits, but the authorities are also concerned about possible terrorist actions politically motivated by authors to determine opponents by violence to meet demands and seek ideological sympathy, often ending with the death of attackers. Piracy is one of the financial sources of terrorism; it is a provider of maritime terrorism or even a generator of it. The center of interest is Somalia, where pirates have prepared people and provided the naval wing of the Al-Shabaab Islamic terrorist organization and helped this organization smuggle weapons. Moreover, it seems that this terrorist group would have planned to sink a ship to block the Suez Canal using Somali pirates.

Other areas at risk of attacks are the Red Sea, Mauritius, Fujairah and Colombo (Sri Lanka). Through the Bab-el-Mandeb Strait of the Horn of Africa, 30\% of maritime traffic passes, the capture of ships is aimed at stealing or redeeming captives and robbing carried goods.

According to the International Maritime Bureau's Report, over 2007-2008, a total of 293 incidents were reported worldwide, 49 ships were hijacked, 889 crew members were taken hostage, 11 were killed and 21 were declared missing. The increase in piracy and armed robbery in the Aden Gulf region and Somalia's east coast is alarming: 111 attacks with 42 hijacked ships. By the end of 2008 , Somali pirates were suspected of seizure of 13 ships for redemption and 242 crew members as hostages. Directly or indirectly, as a result of the attacks, four crew members died, two were injured and another 14 are still missing. 


\section{"Mircea cel Batran" Naval Academy Scientific Bulletin, Volume XX - 2017 - Issue 2 \\ The journal is indexed in: PROQUEST / DOAJ / Crossref / EBSCOhost/ INDEX COPERNICUS/ OAJI / DRJI I JOURNAL INDEX / I2OR / SCIENCE LIBRARY INDEX / Google Scholar / Academic Keys / ROAD Open Access I Academic Resources / Scientific Indexing Services / SCIPIOI JIFACTOR}

The problem of piracy against commercial vessels is a significant threat to international shipping. In 2011, there were 439 pirated attacks and 45 commercial ships were hijacked around the world. 237 of these attacks and 28 of these hijackings took place in the Gulf of Aden, off the coast of Somalia and off the Indian Ocean. Since the spring of 2012, there have been more than 51 attacks in Somalia (121 worldwide), 11 detours in Somalia (13 around the world) and more than 158 hostages taken from Somalia. At present, 15 ships and over 190 sailors are held hostage to Somali pirates for redemption.

Although liner vessels - container ships and roll-on / roll-off vessels are generally considered to have a lower risk of hijacking due to the higher operating speed and freeboard (height above water), Somali pirates attacked 32 ships in 2010 and six were hijacked. In 2011, 65 ships were attacked and one was hijacked. Since the spring of 2012, eight line ships have been attacked and one was hijacked.

Somali pirates are now using commercial ships hijacked as "mother ships" to carry out attacks in the North Sea and near the coastline of India, more than 1500 nautical miles off Somalia. Pirates operate with multiple, high-speed sketches to get closer and to shoot on boats with automatic weapons and rocket propelled grenades (RPGs) in an attempt to slow down or stop the ships, so the pirates can get on board. Once a ship has been hijacked, pirates typically demand a large redemption payment for the safe return of crew, ship and cargo (in the order of tens of millions of US dollars).

A recent report by the NGO Oceans Beyond Pirates (OBP) found that piracy is still spreading and developing. Beyond the High Risk Area, attacks broke out in West Africa with 95 incidents reported in 2016, rising from 54 in 2015. Most of them occurred in Nigerian waters. The report also showed a sharp rise in abduction for the region's redemptions, with 96 hostages taking compared to 44 in the previous year, but only one case of embezzling cargo. West African piracy economic losses rose by more than 10 percent to $\$ 793.7$ million.

The increase in kidnappings and redemptions is worrying because they tend to lead to greater violence. They involve less risk for the pirates themselves and can produce lucrative returns.

Abduction crimes also increased in Asia, where pirates took 67 hostages and killed six sailors in 2016.

Somalia's coast has been relatively quiet last year, with no successful hijackings. But the report noted that shipwrecks in the area fell, which Pigeon thinks played a role in launching attacks in
2017. The perception of shipping risk has fallen, which has given pirates the opportunity to commit attacks. In East Africa, intent and ability to attack have never disappeared.

Means of counteraction

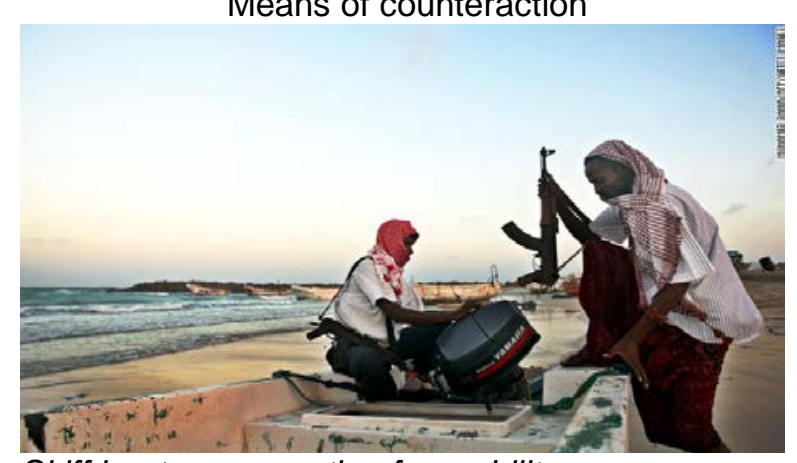

Skiff boat - preparation for mobility

The assessment of the general security situation must be the premise of an abstract threat. There is the possibility of random attacks in order to distract the public from recent ISIS failures (loss of leaders and controlled territories, limitation of financial funds, vulnerability through loss of resources, followers and infrastructure, etc).

In adjacent harbors of the dangerous areas, onboard merchant ships, IMO-authorized security armed teams of mercenary fighters, usually former combatants in Afghanistan, Iraq or Africa, boarding for risk-shield transit. Serious conflicts sometimes occur between ship security crew and shipmaster on navigation control in High Risk Areas, each claiming supreme authority. The failure of the commander's decision would lead to the deregulation of the usual on-board system and the subversion of its authority to the subordinates.

The crew is also ready to use weapons and warning shots can be fired legally into international waters.

The most effective measure remains to avoid areas in which pirates control maritime traffic, which implies knowing the dynamics of the phenomenon in real time through virtual maps and the possibility of using alternative routes to the final destination.

To avoid contact with pirate ships, the classic radar system is used as well as ultra-short wave systems, used to identify small boats. A smart and efficient device launched by British manufacturer BAE Systems is the Watch Stander, which is installed on the side walls of the ship. It identifies small objects and automatically triggers the optical and sound alarm, as well as a high-powered laser beam pointing to the suspect boat. Considered a non-lethal weapon, the ray has a similar effect to the eye 1-mile away as accidentally looking 


\section{"Mircea cel Batran" Naval Academy Scientific Bulletin, Volume XX - 2017 - Issue 2 \\ The journal is indexed in: PROQUEST / DOAJ / Crossref / EBSCOhost/ INDEX COPERNICUS/ OAJI / DRJI I JOURNAL INDEX / I2OR / SCIENCE LIBRARY INDEX / Google Scholar / Academic Keys / ROAD Open Access I Academic Resources / Scientific Indexing Services / SCIPIO/ JIFACTOR}

directly to the sun, making difficult for potential attackers to use weapons effectively (usually AK46 guns and grenade launchers). Attackers become so confused and discouraged.

The device was conceived as a pirates using skiffs (small fishing boats that drop the radar, a device specially designed to filter the waves), boats usually approaching the target ships from the sun direction not to be seen, and tests proved that device can detect the suspect movement before the human senses.

On the other hand, the automatic activation of the device can target innocent fishermen, who come fast behind the ships, knowing that the trail attracts the fish on the surface.

Other dedicated equipment is Directional Sonic Device (pain generator for attackers) or spider cannon (using a compressed air system with projectiles to wrap the enemy boat).

Other measures for commercial ships are to adapt engines for more speed and acceleration in aggressive maneuvers, to build taller walls that are hard to reach from the sea level, to use pressure water hoses to form a virtual wall against pirates and to add security guards, especially in the evening and in the morning, when natural visibility is reduced.

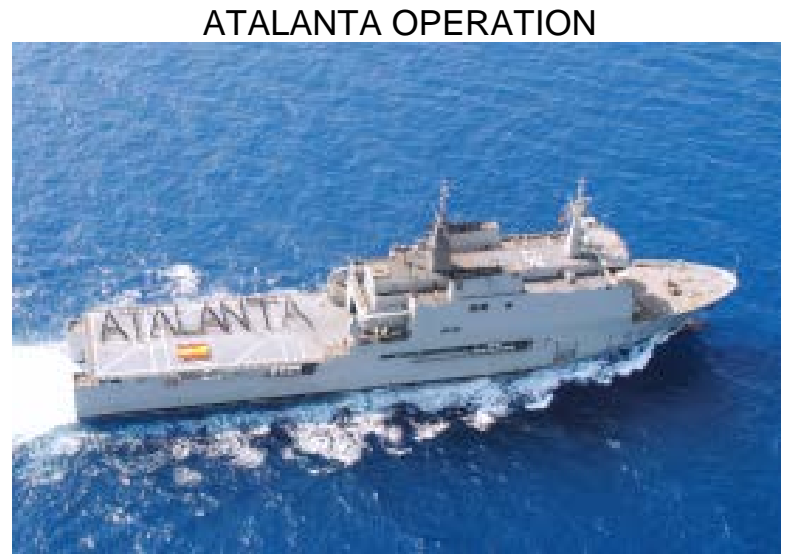

For the boats seized in the Indian Ocean, pirates use tens of millions worth redemption, under the threat of sinking the ship, smuggling the cargo and shooting the crew. Sometimes crew members are even sacrificed to discourage individual acts of heroism or to convey a message about the seriousness of the situation. The other sailors are beaten and tortured, hungry and frightened, to be determined to ask families for the amounts of money claimed. There have been cases in which crews have been detained for 3-4 years before redeeming.

Faced with this threat, the international community chose an aggressive response. In 2008, the European Union, the US and others began to send naval forces to these areas. They are still there today - warships, planes and helicopters, patrolling thousands of square kilometers and doing a loyal job to keep shooters off shore. The UN and the IMO have played an increasingly important role in facilitating negotiations for the release of hostages.

Operation Atalanta is based on the decisions of European Union Council in accordance with the United Nations Security Council Resolution and international law.

In the operational area, active units (naval means - surface ships and auxiliary ships, including embarkation helicopters, sea patrols and reconnaissance aircrafts, ship deployment teams) can arrest, detain and transfer suspected persons for intention to commit or committed acts of piracy or armed robbery at sea.

Operation of Atalanta's assets may confiscate ships suspected of armed piracy or robbery and ships captured by a piracy or armed act.

Suspects may be prosecuted by an EU Member State, States in the region or any other third country who agreed with EU and wishes to exercise its jurisdiction over the suspects of piracy. Suspected pirates may not be transferred to a third State unless the conditions are relevant to international law, in particular to the International Law on Human Right.

Participation in Operation Atalanta goes beyond the EU Member State. Norway was the first non-EU country to have contributed to the Operation with a warship in 2009. Subsequently, Montenegro, Serbia and Ukraine provided state officers at Operations Headquarters (OHQ) and Force Headquarters (FHQ). Ukraine, Colombia and the Republic of Korea have contributed warships and New Zealand has contributed a MPRA.

Changes in Operation Atalanta are consistently routinely rooted in units and vary according to the Indian Ocean monsoon. Under these conditions, it usually includes about 1200 employees, 4-6 surface-combat vessels and 2-3 MPRAs.

In addition to the operations of Atalanta, an international maritime military presence is deployed in the area in a considerable number, including the Combined Maritime Forces (CMF) and independent national units such as China, India, Russia and others - all committed to fighting piracy but with different mandates and various missions.

With up to $95 \%$ of trade in EU Member States (in bulk) transported by sea and $20 \%$ of global trade via the Gulf of Aden, Atalanta attaches considerable importance to the protection of trade through this strategic point. 


\section{"Mircea cel Batran" Naval Academy Scientific Bulletin, Volume XX - 2017 - Issue 2 \\ The journal is indexed in: PROQUEST / DOAJ / Crossref / EBSCOhost/ INDEX COPERNICUS/ OAJI / DRJI I JOURNAL INDEX / I2OR / SCIENCE LIBRARY INDEX / Google Scholar / Academic Keys / ROAD Open Access I Academic Resources / Scientific Indexing Services / SCIPIOI JIFACTOR}

The Horn of Africa Sea Security Center (MSCHOA), located in the OHQ Operations Hall, is an Atalanta Operational Initiative, with close cooperation from industry representatives. MSCHOA provides 24/7 ship monitoring in transit through the Aden Gulf, while providing an Interactive Website allows the Center to communicate the latest anti-piracy guidelines to the maritime industry and for shipping companies and operators to register their ships "Movements through the region ".

Operation Atalanta and other counter-piracy forces can be deployed, as appropriate, in emergency situations.

Data collected in 2017 shows that Atalanta, in cooperation with its counter-piracy partners, has become very effective in preventing attacks before it happens. Together, intelligence-led operations and proactive attitudes, as well as the ongoing effort to support the maritime industry and the commercial community. The importance of selfprotection measures has lowered the success rate of attacks.

At the peak of Somali piracy in January 2011, 736 hostages and 32 ships were held by pirates. By April 2017, their number had fallen to no hostage and no vessel.

Since its launch in 2008, Operation Atalanta has achieved:

- a 100\% success rate in delivering WFP protection delivering food / aid to the Somali people;

- ensuring the protection of other vulnerable transports within the IRTC and the high-risk area;

- has contributed to discouraging, preventing and repressing acts of piracy and armed robbery off the coast of Somalia;

- has transferred the suspected pirates to the competent authorities due to close cooperation with regional governments such as the Republic of Seychelles and Mauritius. This has led to successful prosecution and piratical convictions and seafarers' justice;

- has led and supported numerous SOLAS rescue operations in the area, by supporting local, regional and international trade and fisheries, ships in distress.

Military assets and personnel are provided by the contributing States, with associated running costs and personnel costs being met on a national basis. In addition, there is a common to cover extra costs that are incidental to the operation (specific IT and communication costs and the costs of medical evacuation).

This budget is agreed and monitored by the Athena Committee of the Member States on an annual basis. The budget for 2017 was 5.5 million Euros for the common costs of the mandate.
Information - misinformation

A specific social microclimate, imposed by the roles assumed by the crew, the working conditions in extreme conditions and isolation, the dangers posed by the transported goods and the contrary interests of the parties involved in the business, the internal policy of the company, but the more importantly, by the commander's personality. It imposes the general rules on all sailors, being ultimately responsible for the fate of the crew, the ship and cargo on board (typically worth billions of dollars). There is no democracy allowed on the ship, no politics, history or religion.

There is no tolerance of physical or language violence, private affairs or drug use. Everyone's goal is to strictly fulfill a range of tasks that make the voyage possible, the freight delivered safely and the salary payment on time by each seaman. Under the given conditions, the order is an order, it is executed without comments, like in the army, the mistake or the ignoring of the rules has only one outcome: the crew shift to the next port of call, according to the Masters Standing Orders.

As peculiarities of on-board life in multinational crews, the Indian sailors formally use Hindu language, but coming from different regions, where different dialects are used, they prefer to use English; the Philippines always form a closed group, led by the formal leader, but in many situations there is also another informal leader, with greater authority over the members; Ghanaians have 8 nationalities; Romanians usually comment on the issue of the money they receive and they tend to refuse certain tasks, under the pretext of assuming better-paid colleagues (open or closed over-time).

The master and the captain have medical training and can also provide psychological counseling as needed. The chain control system is strict and efficient, each crew member has access to the feedback through the Open Reporting System mail, contacting the company via the available satellite phone, anonymous letters and the commander's door is always open for discussion on any subject of interest. Contrary to expectations, the onslaught of possible crises onboard does not coincide with tense periods (such as crossing dangerous areas, strong storms, major shortages or failures or pirates' attacks), but on the contrary, with periods of boredom, without concern for sailors, commitment, like waiting in the row for operating.

The appearance of a fishing boat in known risk areas automatically raises the issue of a potential attack by pirates, who look like fishermen and use fishing boats, precisely because they are former fishermen. For this reason, their approach to a commercial ship triggers the pre-attack 


\section{"Mircea cel Batran" Naval Academy Scientific Bulletin, Volume XX - 2017 - Issue 2 \\ The journal is indexed in: PROQUEST / DOAJ / Crossref / EBSCOhost/ INDEX COPERNICUS/ OAJI / DRJI I JOURNAL INDEX / I2OR / SCIENCE LIBRARY INDEX / Google Scholar / Academic Keys / ROAD Open Access I Academic Resources / Scientific Indexing Services / SCIPIO/ JIFACTOR}

procedure, just as the embarkation of passengers on an airplane has as a precursor the total antiterrorist control, even though the overwhelming majority of travelers are far from the kamikaze terrorist profile.

Another point of view of piracy in Somalia

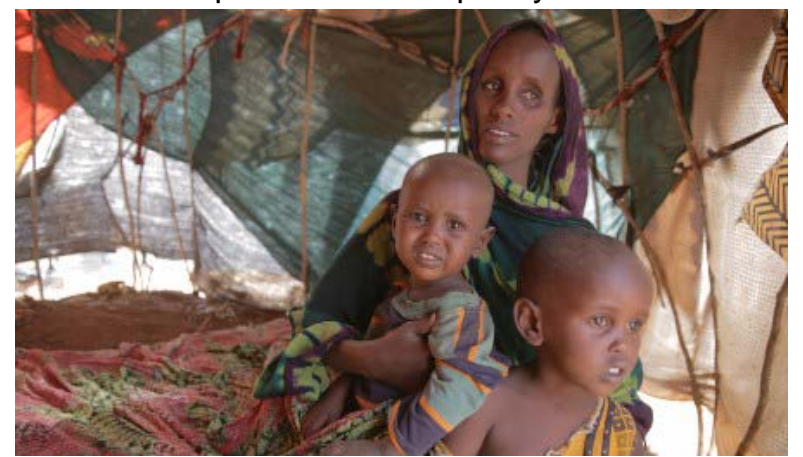

Risk of widespread famine looms over Somalia

Eyl, an ancient city surrounded by the warm blue waters of the Indian Ocean, on the one hand and the Nugaal mountains, on the other - is now known as the capital of piracy in Somalia. Everyone in this town of about 20,000 people has been affected by piracy. Most men were sailors and fishermen. They used to go to sea and stretch or sell nets. Their life was good enough to offer to relatives living in towns and villages far away, paying for rent and tuition fees.

With fishless seas due to poisoned waters by toxic waste and illegal fishing by foreign trawlers and too steep and sterile soil to support agriculture - residents have now exhausted their ideas about how to sustain themselves.

They have consumed all options. Prayers from the local mosque are all that remains in their armor. Dwellings abandoned by ruin are a clear sign that many have given up and left. Life has turned to worst, first the central government collapsed, then the sea was polluted by strangers, using it as a warehouse that killed most of the fish. Life became difficult for all the people in this town. Then the little fish that was left was cleaned by trawlers - illegal trawlers.

For those who chose to stay, piracy was the only way out - the only way they could take to defend the ocean and the little that remained in it. Before the sea was emptied, Somali fishermen never held a gun. Fishing net was their only possession.

Many pirates leave at sea and never come back again. American and European units capture and condemn them to 30 years in prison. The US State Department said more than 1,400 pirates and suspected pirates are in courts or prisons in 21 countries.

More than 200 people in this city have been sent to prisons away from this Horn of Africa country. Over 1,300 young Somali men have been imprisoned abroad for piracy since 2005. Most were sentenced to life in prison.

Inflation in Eyl is high, after millions of dollars have been flooded while redemptions were paid for hijacked ships. Basic goods have become prohibitively expensive for locals. Some traders have pirated money in the past after successful hijackings. One kilo of khat (the narcotic blended with leaves from this part of the world and pirates' favorite) was $\$ 15$, then the pirates came and prices rose to $\$ 50$.

The unanimous feeling in the area is that the international community does not care about the fate of Somalia. They do not care if they die of hunger. They will never arrest anyone for illegal fishing in the waters of Somalia, but they will arrest someone to take a gun to fight trawlers.

\section{CONCLUSION}

Cruises sailing to the sea are seated ducks. The seagoing ship and the passenger ship are not at all certain. Company owners save money and pay for low protection and do not have enough team members on each ship. They should do each port security check for passengers and crew; check the dock, the terminals, especially the buses for excursions and transfer to the city during the standing in the port.

Good connections between the Immigration Authority, Master Port Authority, Police forces, Interpol Division, Hospital, Fire Department, Port Security Authority etc. are required in each port.

The current anti-pirate approach is a lose - lose game, because it does not take into account the initial causes of the phenomenon and does not offer alternative solutions to those involved.

There is an outpouring of local fury over foreign fishermen who occupy their waters. Somalis are also angry on their government, considered weak and corrupt, for licensing some of the foreign fishing vessels.

It is required a robust capacity for the profiling of maritime crime and sharing information among stakeholders in the region. Such capacity would involve the monitoring of transiting vessels, their crews and their ownership with a view to the profiling of suspected vessels and individuals, including activities in coastal communities. A watch list for suspects as well as human accomplices should be developed, updated and shared. 


\begin{abstract}
"Mircea cel Batran" Naval Academy Scientific Bulletin, Volume XX - 2017 - Issue 2
The journal is indexed in: PROQUEST / DOAJ / Crossref / EBSCOhost/ INDEX COPERNICUS/ OAJI / DRJI I

JOURNAL INDEX I I2OR / SCIENCE LIBRARY INDEX / Google Scholar I Academic Keys / ROAD Open Access I Academic Resources / Scientific Indexing Services / SCIPIOI JIFACTOR
\end{abstract}

Somali piracy is a complex issue that needs to be overcome by combining political and diplomatic efforts with military and legal action, development assistance and strong international coordination. With all these instruments at its disposal, the EU is in a unique position to contribute to international efforts.

Attacks have fallen sharply after crews have implemented safety measures and regional naval forces have stepped up patrols. Some pirates have returned to fishing, and others have been involved in smuggling people and weapons along the Red Sea in Yemen.

But if the issue is now under a certain control in Somalia, the same cannot be said for other parts of the world where piracy is on the rise. Wickedness, despair, poverty, greed, even political radicalism brought the phenomenon into the waters of South America, Asia and perhaps most aggressively, in West Africa. It has gradually become clear that piracy in West Africa has many fundamental causes such as piracy in Somalia and elsewhere, not least that those who do not share the benefits and profits of global trade have less and less reasons these days to respect security of those who do.

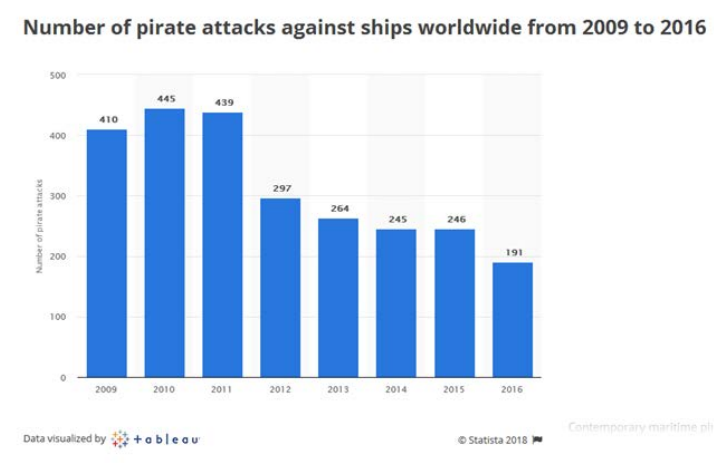

\title{
BIBLIOGRAPHY:
}

[1] GEAMĂNU GRIGORE, Dreptul internaţional penal şi infracţiunile internaţionale, Editura Academiei, Bucureşti, 1977

[2] Arquilla, John, Ronfeldt, David (coord.), Networks and Netwars: the Future of Terror, Crime and Militancy, CA: RAND, Santa Monica, 2001;

[3] PETRACHE ADRIAN-IONEL, Terorismul şi Securitatea României, Editura Universitaţii Naţionale de Apărare, Bucureşti, 2004

[4] MIHEI ANDRIAN SIROJEA, Marea Neagră - Tintă a terorismului maritim în actualul context geopolitic, în Terorismul Azi, an III, nr .XXIV-XXVII, Editura A.S.C.T., Cluj-Napoca, 2008

[5] https://www.icc-ccs.org/piracy-reporting-centre/live-piracy-report

[6] http://time.com/3960691/isis-frigate-egypt-sinai/

[7] http://www.telegraph.co.uk/news/worldnews/islamic-state/11660487/Islamic-State-one-year-on-Where-doits-fighters-come-from.html

[8] http://eunavfor.eu/mission/

[9] https://www.statista.com/statistics/266292/number-of-pirate-attacks-worldwide-since-2006/

[10] http://edition.cnn.com/2017/05/25/africa/piracy-resurgence-somalia/index.html

[11] http://www.noonsite.com/General/Piracy/piracy-reports-2016

[12] https://www.nbcnews.com/news/world/pirates-hijack-oil-tanker-aris-13-somalia-s-coast-officials-n733151

[13] http://www.bbc.com/news/world-africa-22821841

[14] http://www.dryadmaritime.com/combating-piracy-gulf-guinea/ 